\title{
PRELIMINARY OBSERVATIONS ON THE INTERACTION OF DOMPERIDONE WITH PERIPHERAL DOPAMINE RECEPTORS
}

\author{
J.L. WILLEMS, M.G. BOGAERT and W. BUYLAERT \\ Heymans Institute of Pharmacology, University of Gent Medical School. \\ B-9000 Gent, Belgium
}

Accepted October 21, 1980

Domperidone is a specific dopamine antagonist that does not exert central antidopaminergic activity in vivo, probably because it does not readily cross the bloodbrain barrier (Costall et al., 1979; Laduron and Leysen, 1979).

In this study, domperidone has been compared with haloperidol in three different experimental situations where dopamine and/ or apomorphine are known to act: in vivo dopamine-induced ganglionic inhibition (Willems, 1973), in vivo dopamine-induced neurogenic vasodilatation (Willems and Bogaert, 1975) and in vivo apomorphineinduced vasodilatation (Buylaert et al., 1977). The experimental observations suggest that these phenomena are due to an interaction of dopamine, or apomorphine, with a peripheral dopamine receptor in the sympathetic ganglia, or at the sympathetic nerve endings. Domperidone and haloperidol are equipotent as antagonists of these effects on peripheral dopamine receptors.

\section{Dopamine-induced ganglionic inhibition}

Mongrel dogs (4 to $8 \mathrm{~kg}$ ) were anaesthetized with pentobarbitone sodium $30 \mathrm{mg} /$ $\mathrm{kg}$ i.v. The ganglionic preparation was previously described in detail (Willems, 1973). Bipolar electrodes were placed on the cut upper internodal segment of the fourth or fifth paravertebral lumbar ganglion and an electrical stimulus of $0.3 \mathrm{~ms}$ duration and supramaximal intensity was applied at a frequency of $1 \mathrm{~Hz}$. Postganglionic electrical activity was recorded by a second bipolar electrode on the ramus communicans griseus of the ganglion. Drugs were injected into the abdominal aorta at the level of the ganglion studied. Dopamine and apomorphine were used as agonists, domperidone as the antagonist.

\section{Dopamine-induced neurogenic vasodilatation}

Mongrel dogs ( 8 to $15 \mathrm{~kg}$ ) were anaesthetized with pentobarbitone sodium $30 \mathrm{~kg} /$ $\mathrm{kg}$ i.v. The isolated perfused hindleg preparation was previously described in detail (Willems and Bogaert, 1975). The isolated hindleg was perfused at a constant flow with the dog's own blood and changes in perfusion pressure reflect changes in vascular resistance. Drugs were injected into the abdominal aorta at the level of L5. Dopamine was used as the agonist and domperidone and haloperidol as antagonists.

\section{Apomorphine-induced vasodilatation}

Mongrel dogs (10 to $20 \mathrm{~kg}$ ) were anaesthetized with pentobarbitone sodium $30 \mathrm{mg} / \mathrm{kg}$ i.v. Blood flow in both femoral arteries was monitored with electromagnetic flowmeters. Drugs were injected locally into the femoral artery via the arteria femoralis profunda (Buylaert et al., 1977). Apomorphine was used as an agonist and domperidone and haloperidol as antagonists.

a. Dopamine, $16.10^{-8}$ moles, injected into the abdominal aorta, elicited in 5 dogs an 
inhibition of the postsynaptic spike of $81.37 \%$ \pm 8.59 (mean \pm S.E.M.). This dopamineinduced ganglionic inhibition was antagonized by $30 \mu \mathrm{g}$ of domperidone: after domperidone, dopamine $16.10^{-8}$ moles gave an inhibition of $13.40 \% \pm 4.97(P<0.01)$.

b. In a series of 10 dogs, domperidone or haloperidol was administered in three doses. 1. 10 and $100 \mu \mathrm{g}$ at $30 \mathrm{~min}$ interval. In another 5 dogs the solvent (lactic acid $0.1 \mathrm{~N}$ ) was injected. The neurogenic vasodilatation, elicited by $16.10^{-8}$ moles of dopamine injected into the abdominal aorta, obtained after a given dose of the antagonist is expressed as a percent of the control neurogenic vasodilatation. Table 1 summarizes the results obtained. Solvent injections did not modify the dopamine neurogenic vasodilatation.

c. Apomorphine, 0.25-0.5 . 10-8 moles, injected directly into the femoral artery. elicits a specific, short-lasting vasodilatation without any systemic effect. This vasodila- tation is due to an inhibitory effect of apomorphine on the transmitter release from the sympathetic nerve endings. This effect is mediated by a specific dopamine receptor (Buylaert et al., 1977; Enero and Langer. 1975: Long et al., 1975). Table 2 summarizes the results obtained with domperidone (4 experiments) and with haloperidol (7 experiments). The increase in femoral flow is given as a percent of the preexisting flow. Haloperidol and domperidone, in a dose of about $10 \mu \mathrm{g}$, blocked the apomorphineinduced vasodilatation to a great extent and a competitive antagonism may be involved here.

The neurogenic vasodilatation elicited in the isolated perfused hindleg by the intraaortic administration of dopamine, is due to an inhibitory effect on the paravertebral sympathetic ganglia (Willems and Bogaert, 1975). Furthermore this dopamine-induced ganglionic inhibition is mediated by a specific dopamine receptor, which is blocked

Table 1. Neurogenic vasodilatation ( $\%$ of control) by dopamine $16.10^{-8}$ moles given intraaortically after increasing doses of haloperidol and domperidone (mean \pm S.E.M.)

\begin{tabular}{clll}
\hline & $1 \mu \mathrm{g}$ & $10 \mu \mathrm{g}$ & $100 \mu \mathrm{g}$ \\
\hline Haloperidol & 68.84 & 37.21 & 9.30 \\
$(n=5)$ & \pm 1.86 & \pm 4.19 & \pm 3.72 \\
Domperidone & 65.12 & 34.42 & 4.65 \\
$(n=5)$ & \pm 11.16 & \pm 8.37 & \pm 3.26 \\
\hline
\end{tabular}

Table 2. Increase in femoral flow (\% of previous resting flow) by apomorphine $(0.25$ $-0.5 .10^{-8}$ moles) given intraarterially before and after haloperidol $(n=7)$ or domperidone $(n=4) *($ Mean \pm S.E.M.)

\begin{tabular}{ccc}
\hline Before & After haloperidol $(5-30 \mu \mathrm{g})$ & $5.71 \%$ \\
$138.02 \%$ & \pm 5.71 \\
\pm 28.84 & After domperidone $(10 \mu \mathrm{g})$ & \\
\hline Before & $37.00 \%$ & \\
\hline $322.50 \%$ & \pm 25.84 \\
\hline 105.90 & & \\
\hline
\end{tabular}

*0.5.10-8 moles apomorphine was used when $0.25 .10^{-8}$ moles did not produce a marked vasodilatation, in such a case $30 \mu \mathrm{g}$ was used for haloperidol. 
by haloperidol (Willems, 1973). The results presented herein show that domperidone also antagonizes this specific dopamine effect and that in that respect it is equipotent with haloperidol.

The apomorphine-induced vasodilatation in the femoral vascular bed is due to an interaction with a receptor which has the characteristics of a dopamine receptor: the effect can selectively be blocked by haloperidol and (+)-butaclamol but not by (-)-butaclamol (Buylaert et al., 1977). Our results show that domperidone and haloperidol are equipotent as antagonists of these effects on peripheral dopamine receptors.

\section{REFERENCES}

1) Buylaert, W.A., Willems, J.L. and Bogaert, M.G.: Vasodilatation produced by apomorphine in the hindleg of the dog. J. Pharmacol. exp. Ther. 201, 738-746 (1977)
2) Costall, B., Fortune, D.H. and Naylor, R.J.: Neuropharmacological studies on the neuroleptic potential of domperidone (R33812). J. Pharm. Pharmacol. 31, 344-347 (1979)

3) Enero, M.A. and Langer, S.Z.: Inhibition by dopamine of ${ }^{3} \mathrm{H}$-noradrenaline release elicited by nerve stimulation in the isolated cat's nictitating membrane. Naunyn-Schmiedeberg's Arch. Pharmacol. 289, 179-203 (1975)

4) Laduron, P.M. and Leysen, J.E.: Domperidone, a specific in vitro dopamine antagonist, devoid of in vivo central dopaminergic activity. Biochem. Pharmacol. 28, 2161-2165 (1979)

5) Long, J.P., Heintz, S., Cannon, J.G. and Kim, J.: Inhibition of the sympathetic nervous system by 5.6-dihydroxy-2-dimethylamino tetralin (M-7), apomorphine and dopamine. J. Pharmacol. exp. Ther. 192, 336-342 (1975)

6) Willems, J.L.: Dopamine-induced inhibition of synaptic transmission in lumbar paravertebral ganglia of the dog. Naunyn-Schmiedeberg's Arch. Pharmacol. 279, 115-126 (1973)

7) Wiliems, J.L. and Bogaert, M.G.: Dopamineinduced neurogenic vasodilatation in isolated perfused muscle preparation of the dog. Naunyn-Schmiedeberg's Arch. Pharmacol. 286, 413-428 (1975). 